\title{
Vaccination of health care workers in Romania
}

\author{
Daniela Pițigoi ${ }^{1,2^{*}}$, Liliana Lucia Preoțescu ${ }^{1,2}$, Anca Streinu-Cercel ${ }^{1,2}$, Maria Nițescu $^{1,2}$, Victoria Aramă ${ }^{1,2}$, \\ Alexandru Rafila ${ }^{1,2}$ \\ From The 10th Edition of the Scientific Days of the National Institute for Infectious Diseases "Prof Dr Matei \\ Bals" \\ Bucharest, Romania. 15-17 October 2014
}

\section{Background}

We aimed to review existing regulations about HCWs vaccination in Romania and to identify the attitude and barriers to immunizations of $\mathrm{HCW}$ s through qualitative research.

\section{Methods}

We collected information about $\mathrm{HCW}$ s vaccination policies and regulation implemented through laws and also data about specific vaccination (seasonal influenza, hepatitis $\mathrm{B}$, measles, mumps, rubella and varicella). We conducted 5 focus groups with 39 participants (nurses, physicians, infection control personnel, public health and policy makers), as part of the HProImmune (Promotion of Immunizations for Health professionals in Europe) project activities, in order to understand the risk perception behaviors towards vaccination and barriers stopping HCWs from immunization. We followed for each focus group a specific discussion guide elaborated by the HProImmune project.

\section{Results}

Each health facilities organize yearly influenza vaccination campaigns and HCWs received influenza vaccine at their work place, being covered from the Ministry of Health budget. No specific national recommendation regarding HCWs vaccination against varicella, pertussis, tetanus, diphtheria, poliomyelitis, meningoccocus exist in Romania. The main barriers included: insufficient information on benefits of vaccines, insufficient information on diseases and the risk of diseases, concerns about vaccine effectiveness and adverse events, lack of time, lack of clear national guideline concerning the HCW immunization. Dominant immunization enablers included: influence of educational

\footnotetext{
* Correspondence: danielapitigoi@yahoo.co.uk

${ }^{1}$ Carol Davila University of Medicine and Pharmacy, Bucharest, Romania
}

Full list of author information is available at the end of the article programs (in school and at the workplace) and communication campaigns, importance of hospital epidemiologist, infection control personnel and occupational physicians. The majority of HCWs highlighted that the immunizations should be mandatory in health care facilities.

\section{Conclusion}

Clear immunization policy and guidelines regarding occupational vaccination of HCWs in Romania, communication strategy and training programs are needed in order to increase confidence in vaccine and the vaccination coverage among HCWs.

\section{Authors' details}

${ }^{1}$ Carol Davila University of Medicine and Pharmacy, Bucharest, Romania. ${ }^{2}$ National Institute for Infectious Diseases "Prof. Dr. Matei Balş", Bucharest, Romania.

Published: 15 October 2014

doi:10.1186/1471-2334-14-S7-P75

Cite this article as: Pițigoi et al: Vaccination of health care workers in Romania. BMC Infectious Diseases 2014 14(Suppl 7):P75.

Submit your next manuscript to BioMed Central and take full advantage of:

- Convenient online submission

- Thorough peer review

- No space constraints or color figure charges

- Immediate publication on acceptance

- Inclusion in PubMed, CAS, Scopus and Google Scholar

- Research which is freely available for redistribution

Submit your manuscript at www.biomedcentral.com/submit

\section{() Biomed Central}

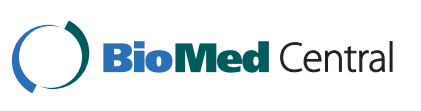

2014 Pitigoi et al; licensee BioMed Central Ltd. This is an Open Access article distributed under the terms of the Creative Commons Attribution License (http://creativecommons.org/licenses/by/4.0), which permits unrestricted use, distribution, and reproduction in any medium, provided the original work is properly cited. The Creative Commons Public Domain Dedication waiver (http:// creativecommons.org/publicdomain/zero/1.0/) applies to the data made available in this article, unless otherwise stated. 